\title{
The Effects of Organizational Culture, Learning Organization, Empowerment, and Organizational Commitment on the Performance of SMEs (A Case Study of SMEs in the Regency of South Minahasa)
}

\author{
Johny Tarore \\ Faculty of Economics, Manado State University
}

\begin{abstract}
This study aimed at investigating the effects of (1) organizational culture on organizational commitment, (2) learning organization on organizational commitment, (3) empowerment on organizational commitment, (4) organizational culture on the performance of SMEs, (5) organizational commitment on the performance of SMEs, (6) learning organization on the performance of SMEs, and (7) empowerment on the performance of SMEs. The study employed a quantitative approach. As many as 354 samples of enterprise owners served as the variable of SMEs performance. The employees served as the variable of organizational culture, learning organization, empowerment and organizational commitment on SMEs in 17 districts in the Regency of South Minahasa. Data were then analyzed using SEM (Structural Equation Modelling) and further tested using CFA (Confirmatory factor Analysis). Based on the findings, it was be concluded that there were six significant and direct effects, namely: (1) Organizational Culture had a direct effects on organizational commitment (2) Learning organization had a direct effects on organizational commitment (3) Empowerment had a direct effects on the performance of SMEs (4) Organizational Culture had a direct effects on the performance of SMEs (5) Organizational Commitment had no direct effects on the performance of SMEs (6) Learning organization had a direct effects on the performance of SMEs, and (7) Empowerment had a direct effects on the performance of SMEs
\end{abstract}

\section{Introduction}

Small and medium enterprises in Indonesia are arguably a pillar of national economy. In 2013 alone, the report showed there were 56.5 million units of enterprises which made up $99 \%$ of total business in Indonesia (Kompas Newspaper, October 25, 2013). The business contributed 57.95\%, that is, IDR 4,303.57 trillion, with the total value of investment IDR 830.9 trillion on gross domestic products (GDP). Accordingly, the business provided employment for 110.80 million people (Data from the Ministry of Small and Medium Enterprises in 2013). In regards of the potentials of SMEs, the contribution to the gross domestic products (GDP) was conceivably bigger than 58\%. Regardless of their extensive proportion compared to large enterprises in terms of the contribution to the GDP, it was not due to high productivity. Rather, according to Tambunan (2009:60), it was caused by their collosal amount of units in comparison to large enterprises. In other words, large enterprises both totally and partially still have higher productivity rather than their SME conterparts. Furthermore, Tambunan (2008:1-2) reported an empiric study showing that up to nowadays, low contributions of SMEs to the economy in developing countries are results of low level of skills and education, lack of capital, and government's policies not favoring SMEs. Additionally, Budiretnowati (2008:14) believed that SME owners were lacking knowledge about the economic value of their products, thus prevented them from gaining profit appropriately in accordance to the added value they created.

In 2014, The Government of the Regency of South Minahasa designed an extensive promotional and marketing strategy of SMEs in conjunction to tourism. In this regards, the government sought to provide business locations which at the same time created tourist attractions.

Challenges to the implementation and development of small and medium enterprises are classified into two categories, namely internal challenges and external challenges.

Internal challenges are as follows.

(1) Lack of awareness and willingness of the business owners to implement science and technology.

(2) Lack of capital to support improvement of technology.

(3) Lack of ability to make use of business opportunities.

(4) Limited access and information about certain technology and science 
External challenges are as follows.

(1) Minimal process of technology transfer, one of the cases being shortfall of counselling experts, and

(2) Limited options of funding schemes for the development of science of technology, one of which is leasing system.

\section{Theoretical Review}

According to O'Reilly et.al (in Tepeci, 2001) organizational culture refers to several dimensions, namely, people orientation, team orientation, innovation, outcome orientation, attention to detail, and stability. According to Utomo (2004), dimensions of empowerment are business counselling, business facility, service, market development and education. According to Meyer and Allen in Luthan (2008:147) dimensions of organizational commitment are affection, continuity and norms. According to Riyanti (2003); Robbins (2000); Terziouski \& Samson (2000); and Brealey \& Gitmen in Sangen (2005) dimensions of performance of SMEs are level of income during past 3 years, profit, volume growth during past 3 years, market coverage, selfsatisfaction as an entrepreneur, supportive working environment, employee growth, conflict of surrounding environment due to the operating equipment/machines, and environmental awareness.

The conceptual model being reviewed in this study is presented as follows.

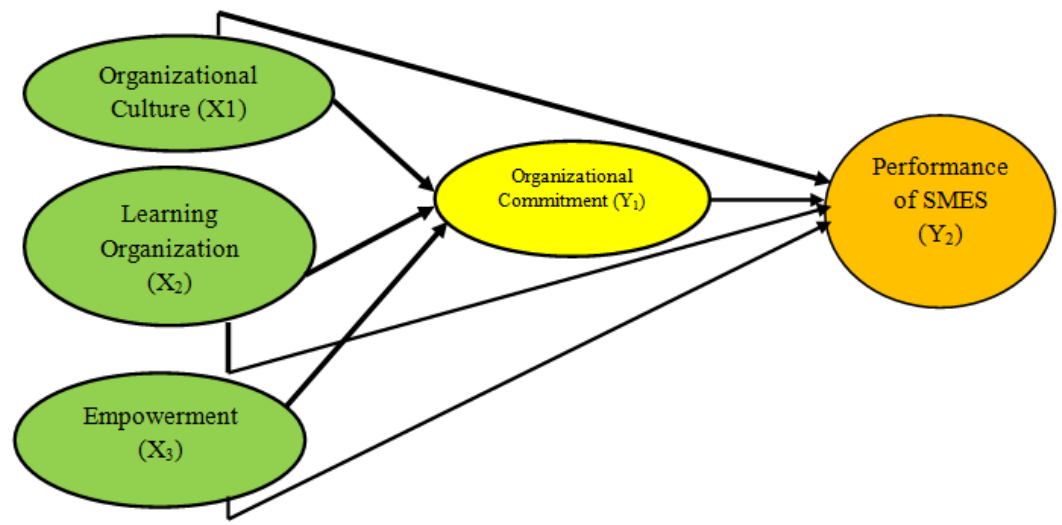

Figure 1 Conceptual Model of the Study

The conceptual model straightforwardly reflects the status of each variable of the study comprising three types, i.e. antecedent variable, intervening variable and consequence variable. Antecedent variables are preceding variables that cause impacts. Antecedent variables being investigated were organizational culture, learning organization, and empowerment. Next are intervening variables, which are intermediating variables or in-between variables. The intervening variable being investigated was organizational commitment. The last is consequence variable, which is resulted variable. In this case, it was the performance of SMEs.

\section{Findings}

Alternative Model Using Structural Equation

The model illustrating inter-variable relationships is shown as follows.

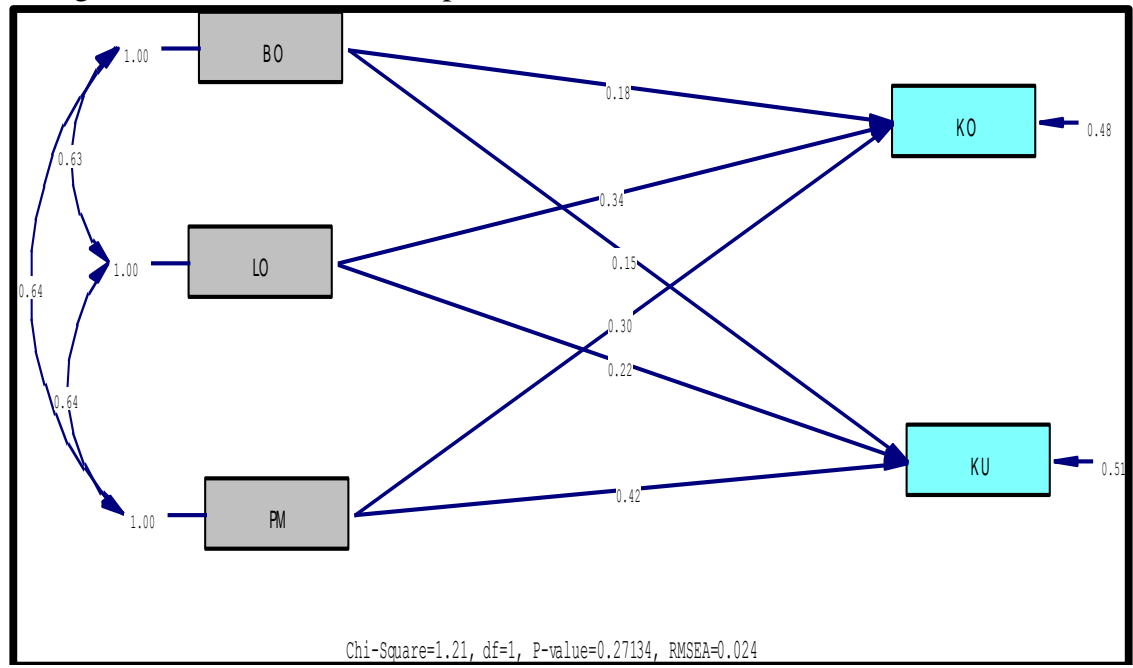

Figure 2 Alternative Model (Standardized) 
Consequently, it is safe to assume that the alternative model had goodness of fit to be made a model. The adequacy of its compliance is displayed below.

Table 1 Goodness of Fit Test on Final Model

\begin{tabular}{|l|l|l|l|}
\hline Factor & Coefficient & Criteria & Conclusion \\
\hline Chi-Square $\left(\chi^{2}\right)$ & 1.21 & Small (non-significant) & comply \\
\hline P-value & 0.27 & $\geq 0.05$ & comply \\
\hline Df & 1 & --- & --- \\
\hline Cmin $\left(\chi^{2} /\right.$ Df) & 1.21 & $\leq 2.00$ & comply \\
\hline RMR (standardized) & 0.036 & $\leq 0,08$ & good \\
\hline RMSEA & 0.024 & $\leq 0,08$ & good \\
\hline GFI & 1.00 & $\geq 0,90$ & perfect \\
\hline AGFI & 0.98 & $\geq 0,90$ & good \\
\hline CFI & 1.00 & $\geq 0,94$ & perfect \\
\hline IFI & 1.00 & $\geq 0,94$ & perfect \\
\hline NFI & 1.00 & $\geq 0,94$ & perfect \\
\hline AIC $($ Model $)$ & 29.21 & small, relative & good \\
\hline
\end{tabular}

Table 4.19 above showed that all criteria of the goodness of fit model complied in terms of AIC, $\mathrm{Cmin} / \mathrm{df}$, and p-value. In addition to that, the value of CFI (Comparative Fit Index), IFI (Incremental Fit Index) and NFI was each 1. It showed that the model had the best alignment (Arbucke \& Wothke, 1999). Therefore, it can be inferred that empirically the model complied the actual condition.

\section{Discussion}

\section{Organizational Behaviour had direct effects on organizational commitment}

Hypothesis testing 1 showed a $\mathrm{t}$-value of $3.46\left(>\mathrm{t}_{\text {table }} 1.96\right)$ which was conclusive and significant. This indicated that organizational culture had direct effects on organizational commitment.

Findings of the study showed that directly organizational culture gave total effects of 0.18 on organizational commitment. It is understandable because organizational culture is a foundation of a company: it is difficult to keep the existence of a company if the organizational culture is weak. Accordingly, it is imperative that organizational culture be strong to maintain the existence of a company.

In regards to organizational commitment, organizational culture is an internal environment of an organization to facilitate, support and give opportunities to its employees to actualize their commitment to escalate SMEs through their roles. Commitment of the employees is critical to ensure the performance of SMEs. In other words, when there is strong organizational culture within a SME, there is an effect on the commitment of the employees. The notion is in accordance to Robbins (2001:528) who maintains that one of functions of organizational culture is facilitating revitalization of commitments to something bigger than an individual interest. Reviews of preceding studies found conformable theory, some of which are those by Greenberg \& Baron (2013:518), Robbins (2001:528), Elzbieta Sikorska-Simmons (2005), Odom, et.al. (1990) and Elizur \& Koslowsky (2001).

\section{Learning organization had direct effects on organizational commitment}

Hypothesis testing 2 showed an estimated result of the model having $t$-value of $6.62\left(>t_{\text {table }} 1.96\right)$ which was conclusive and significant. This indicated that learning organizational had direct effects on organizational commitment.

Findings of the study showed a direct effect of learning organization on organizational commitment with a total value 0.34. Learning organization manifested in training, mentoring and experience. Among the three manifests, monitoring has the highest loading value. It suggested that successful mentoring affects employee commitment, which in turn will affect the increasing performance of SMEs. The theory is in line with findings from Xianting \& Fungfai (2010) which shows that organizational learning culture has a positive influence on organizational commitment through mentoring. The finding is similar with preceding studies by Jun \& Kyoo (2011), Chaoo (2007), Barlett (2004), Kyoo, (2011), Xianting \& Fungfai (2010), and Tseng (2010).

\section{Empowerment had direct effects on Organizational Commitment}

Hypothesis testing 3 showed an estimated result of the model having t-value of $5.79\left(>t_{\text {table }} 1.96\right)$ which was conclusive and significant. This indicated that empowerment had direct effects on organizational commitment.

Findings of the study showed a direct effect of empowerment on organizational commitment with a total value 0.30. Empowerment of employees are presented by SMEs by giving them business training both inside and outside the company. Employees are expected to gain knowledge about market, asset and technology. This way, it is projected that their organizational commitment boosted. In regards of creating work fields, 
business training given to social groups in rural areas is projected to generate economic independence in SME. It is therefore expected that a person given training will be more motivated to create their own labour. In other words, empowerment affects organizational commitment. This is in accordance to previous studies conducted by Corsun \& Enz (1999) and Koberg et.al. (1999).

\section{Organizational Culture had a direct effect on the performance of SMEs}

Hypothesis testing 4 showed an estimated result of the model having t-value of $7.43\left(>t_{\text {table }} 1.96\right)$ which was conclusive and significant. Findings of the study showed a direct effect of organizational behaviour on the performance of SMEs with a total value 0.15. This indicates that strong values of organizational culture shared by employees contribute to the performance of SMEs. The stronger the organizational culture, the better the performance of the SMES. This finding is in conformity by previous studies conducted by Djoko Santoso (2003), Pastin (1986; 272), Chatman \& Bersade (1997), as well as Bintoro (2002).

\section{Organizational Commitment had no direct impact on the performance of SMEs}

Hypothesis testing 5 showed that organizational commitment had direct effects on the performance of SMEs. However, the findings suggested that the effects were not direct. Based on the simulation of model using structural equation modelling, the direct effects of organizational commitment on the performance of SMEs were eliminated. The absence of direct influence of organizational commitment on the performance of SMEs was feasibly due to the fact that every so often the existing theory did not always reflect the real condition.

Due to the absence of direct effects of organizational commitment on the performance of SMEs in this study, it is recommended that further study be carried out to investigate the relationship. However, at the moment it is believed that there is influence, though indirect.

\section{Learning organization had a direct effect on the performance of SMEs}

Hypothesis testing 5 showed an estimated result of the model having t-value of $4.10\left(>t_{\text {table }} 1.96\right)$ which was conclusive and significant value. It indicated that learning organization had direct effects on the performance of SMEs.

Findings of the study showed a direct effect of learning organization on the performance of SMEs with a total value of 0.22 . This suggested that learning organization influenced the performance of SMEs - in a way that employees' strong learning organization was built by giving them training, mentoring and experiences, there would be increasing performance of the SMEs.

This finding is in accordance to previous studies conducted by Hurly \& Hult (1998) and Antariksa (2000).

\section{Empowerment had a direct effect on the performance of SMEs}

Hypothesis testing 7 showed an estimated result of the model having $t$-value of $7.76\left(>t_{\text {table }} 1.96\right)$ which was conclusive and significant. This suggested that empowerment had direct effects on the performance of SMEs.

Findings of the study showed direct effects of empowerment on the performance of SMEs with a total value of 0.42 Empowerment in this study was demonstrated in the facilitating technology and machines. This process of providing facilities is assumed to influence the business independency of the entrepreneurs of SMEs. This is regarded to lead to the betterment of their life qualities. In short, successful empowerment positively affects the performance of SMEs. This finding is in accordance to previous studies conducted by Xavier et.al, (2006), Vincent (2005) and Rice (2000).

\section{Conclusion}

This study aimed at investigating the relationship of Organizational Culture, Learning Organization, Organizational Commitment and Empowerment on the Performance of SMEs. Subjects of the study were owners of SMEs. Object of the study were SMEs in 17 Districts in the Regency of South Minahasa.

Based on the finding, there were six definite relationships and one indefinite relationship. The summary is as follows:

(1) Organizational culture had direct effects on organizational commitment. The t-value was at 3.46 (> $t_{\text {table }}$ 1.96). Findings of the study showed that directly organizational culture gave total effects of 0.18 on organizational commitment. This suggests that high organizational culture in the SMEs positively affects the organizational commitment of the employees.

(2) Learning organization has direct effects on organizational commitment. The t-value was at $6.62\left(>t_{\text {table }} 1.96\right)$. Findings of the study showed a direct effect of learning organization on organizational commitment with a total value of 0.34 . It indicated that successful learning organization affects organizational commitment. 
(3) Empowerment had direct effects on organizational commitment. The $t$-value was at $5.79\left(>_{\text {table }} 1.96\right)$. Findings of the study showed a direct effect of empowerment on organizational commitment with a total value of 0.3 . It indicated that successful empowerment affected organizational commitment.

(4) Organizational culture had direct effects on the performance of SMEs. The t-value was at 7.43(>t table 1.96$)$. Findings of the study showed a direct effect of organizational culture on the performance of SME with a total value of 0.15 . It indicated that strong organizational culture affected the performance of SMEs.

(5) Organizational commitment had no proved direct effects on the performance of SMEs. Findings of the study showed no effects of organizational commitment on performance of SMEs. It was allegedly due to discrepancies between the theory and the factual conditions of the populations. Further studies are crucial to investigate the effects of organizational commitment on the performance of SMEs under different circumcisions.

(6) Learning organization had direct effects on the performance of SMEs. The t-value was at 4.10(>t $\left.t_{\text {table }} 1.96\right)$. Findings of the study showed a direct effect of learning organization on the performance of SME with a total value of 0.22 . It indicated that strong learning organization affected the performance of SMEs.

(7) Empowerment had direct effects on the performance of SMEs. The t-value was at 7.76(> table 1.96$)$. Findings of the study showed a direct effect of empowerment on the performance of SME with a total value of 0.42. It indicated that strong empowerment affected the performance of SMEs.

\section{Recommendations}

Education is crucial to ensure the promptness of prospective SME entrepreneurs in the future. Based on the findings, there are two types of recommendation can be given, i.e. formal education and informal education as described below.

\section{Formal Education}

1) Establishing more vocational schools with special business-based curriculum to prepare students knowledge about entrepreneurship and provide them with real life skills on managing enterprises.

2) Establishing polytechnics with a study program of business.

3) Reconstructing curriculum in schools to give more focus on economics and business.

4) Establishing training institutions on SME activities to provide labours for the enterprises.

\section{Informal Education}

Strengthening independent groups in rural areas by giving the people training and counselling on how to run the business.

\section{Reference}

[1]. Ackfeldt, A.L., dan Coote, L.V., 2000. An investigation into the antecedents of organizational citizenship behaviours, ANZMAC,Visionary Marketing for the $21^{\text {st }}$ Century: Facing the Challenge.

[2]. Arbuckle, Jl., and Wythe, W., 1999. Amos 4.0 User's Guide. Chicago: Small Waters Corporation.

[3]. Coolican, H., 1994. Research Methods and Statistics in Psychology. London: Hodder\& Stoughton.

[4]. Chen, Z.X., 1998. The effects of loyalty in supervisor on job satisfaction and intention to stay: a Chinese case. Paper, Hongkong: School of Business, Hongkong Baptist University.

[5]. Chuang, Y., Church, R., and Zikic, J., 2004.Organizational culture, group diversity and intra-group conflict. The Performance Management, $10(1 / 2):$ 26-34.

[6]. Chao, C.S Lee., S.M. 2007, A Study on relationship among leadership, organization; Culture, the operation of learning Organization and Employees Job Satisfaction, The Learning Organization, Vol 14 No. 2, pp.155-185.

[7]. Daniel, W.W., and Terrell, J.C., 1989. Business Statistics for Management and Economics. Boston: Houghton Mifflin Company.

[8]. Egan, T.M Yang, B Barlett, K.R. 2004, the Effect or organizational Learning Culture and job Satisfaction on Motivation to transfer Learning and Turnover Intention, Human Resource Development Quarterly, Vol 15, No. 3, pp 279-301.

[9]. Elzbieta, (2005). "Predictors of Organizational Commitment among Staff in Assisted Living." The Gerontological Society of America Vol. 45, No. 2, 196-205.

[10]. Freund, A., and Carmeli, A., 2003. An empirical assessment: reconstructed model for five universal forms of work commitment. Journal of Managerial Psychology, 18 (7): 708-725.

[11]. Greenberg, Jerald and Robert A. Baron. Behavior in Organizations. New Jersey: prentice-Hall International, Inc., 1997.

[12]. Greenberg, J. and Baron, R. A. 2003. Behavior in Organizations: Understanding and Managing the Human Side of Work. New Jersey: Pearson Education International.

[13]. Gujarati, D.N., 1995. Basic Econometrics. New York: McGraw-Hill, Inc.

[14]. Gay, L.R., and Diehl, P.L., 1992. Research Methods for Business and Management. New York: Macmillan Publishing Company.

[15]. Guy,V(nd); Sustainable micro-entrepreneurship : the Roles of microfinance, Entrepreneurship and sustainability in reducing poverty in developing country.(journal of business and social science vol. 4).

[16]. Hurley, Robert F. and G. Thomas, M. Hult, 1998. Innovation, Market Orientation, and Organizational Learning an Integration and Empirical Examination. Journal of Marketing, Vol. 62, p. 42-54.

[17]. Hasan, M.Z., 1998. Analisis Faktor. Makalah disampaikan pada lokakarya statistik dan analisis data penelitian, Malang: Lembaga Penelitian Universitas Negeri Malang (IKIP Malang). 
[18]. Jun Jo, S, Baek K.J (2011) Knowladge Sharing : The influences of learning organization Culture, Organizational Commitment and Organizational Citizenship Behaviors, Journal Commitment and Organizational Citizenship Behaviors, Journal of leadership \& Organizational Studies, Vol 25 No 4, pp 11 -14.

[19]. Jennifer M.G \& Jones G.R, 2007.Understanding and Managing Organizational Behaviour.Fifth Edition.Pearson Prentice Hall. New Jersey.

[20]. Jernigan III, I.E., Beggs, J.M., and Kohut, G.F., 2002. Dimensions of work satisfaction as predictors of commitment type. Journal of Managerial Psychology, 17 (7): 564-579.

[21]. Jogaratnam, G., and Buchanan, P., 2004. Balancing the demands of school and work: stress and employed hospitality students. International Journal of Contemporary Hospitality Management, 16 (4): 237-245.

[22]. Kyoo, B.J Park, S. 2010 Career satisfaction, organizational commitment and turnover intention. The effect of goal orientation, organization learning culture and development feedback, Leadership \& Organizational Studies, Vol 16, No 1 pp 48-60.

[23]. Kreitner, Robert And Angelo Kinicki. 2005. Perilaku Organisasi, Edisi 5. Alih bahasa Erly Suandy. Jakarta: Salemba Empat.

[24]. Kreitner, R., and Kinicki, A., 2008. Organizational Behavior.8th Edition. New York: McGraw-Hill.

[25]. Keller, R. T. 1997. Job Involvement and Organizational Commitment as Longitudinal Predictors of Job Performance: A Study of Scientists and Engineers. Journal of Applied Psychology 82(4): 539- 545.

[26]. Kunene, Thandeka R., 2008, A Critical Analysis of Entrepreneurial and Business Skills in SMEs in the Textile and Clothing Industry in Johannesburg, South Africa, University of Pretoria.

[27]. Lipshitz, R., Popper, M., \& Friedman, V. J. (2002).A multifaceted model of organizational learning. The Journal of Applied Behavioral Science, 38(1), 78-98.

[28]. Luthans, Fred. 2006. Organizational Behavior.7-Ed. Mc.Graw-Hill International, New York.

[29]. Lok, P., and Crawford, J., 2001.Antecedents of organizational commitment and the mediating role of job satisfaction. Journal of Managerial Psychology, 16 (8): 594-613.

[30]. Tseng, C. (2010), The Effects of learning organization Practices on Organizational Commitment and Effectiveness for small and medium- Size Enterprises in Taiwan, Dissertation Submitted to the Faculty of the Graduate School of the University of Minnesota.

[31]. Meyer, J.P., Allen N. j \& Smith, Catheride A. 2003 HRM Practices and Organizational Commitment: Test of a Mediation Model. Canadian Journal of Administrative Science. Vol.7.No 4, pg.319-331.

[32]. McShane, Stephen L and Von Glinow, Mary Ann. 2005. Organizational Behavior: Emerging Realities for the Workplace Revolution, second Ed, McGraw-Hill, Irwin.

[33]. McCall, R.B., 1986. Fundamental Statistics for Behavioral Sciences. Sandiego: Harcourt Brace Jovanovich, Publishers

[34]. M.J. Xavier, J Raja, S Usha Nandini (2007), impact of Entrepreneurship Development through corporate interventions; An Assessment of the case of $\mathrm{H}^{\prime \prime} \mathrm{LL}_{\mathrm{s}}$ Project shakti, (Advances in international management volume 20).

[35]. Makinen, H. 2000. Product Design as Core Competence in a Design Oriented Industry. Turku School of Economics and Business Administration.

[36]. Niehoff, B.P., and Moorman, R.H., 1993. Justice as a mediator of relationship between methods of monitoring and organizational citizenship behavior. Academy of Management Journal, 36 (3): 527-556.

[37]. Odom, Rendal, Y., Boxx, W.R.,\& Dunn, M.G.1990. Organizational Culture, Commitment, Satisfaction, and Cohesion. Public Productivity \&Management Review, 14 (2), 157-169.

[38]. Oxaal, Z. and Bade. S. 1997 Gender and Empowerment : Definitions, Approaches \& Implications for policy. Report 40 for the Swedish International Development Studies. University of Sussex, Brigton UK.

[39]. Peter, M Senge. (alih bahasa oleh Ir. Hari Suminto). The Fifth Discipline: The Artand Practice of the Learning organization. (2003). Batam Centre: Ineraksara.

[40]. Robbins Stephen P., 2001. Organizational Behavior (Terjemahan) Jilid 1, Edisi Kedelapan, PT. BhuanaI lmu Populer, Jakarta.

[41]. Robbins Stephen, 2003. Perilaku Organisasi: Konsep, Kontroversi, dan Aplikasi. Alih Bahasa Handayana Pujaatmika. Edisi Bahasa Indonesia. Jakarta: Prenhalindo.

[42]. Robbin Stephen, and Judge, Timothy.2009. Organizational Behavior $13^{\text {th }}$ edition. Pearson International Edition

[43]. Robert L. Mathis and John H.Jackson. 2006. Human Resources Management. Salemba empat Jakarta.

[44]. Rusidi,1990, Dasar - dasar Penelitian.Bandung : Program Pascasarjana Universitas Padjajaran.

[45]. Rue, L.W. \&Byars, L. 1997. Management: Theory and Application, Homewood Illinois: Richard D. Irwin, Inc.

[46]. Roscoe, J.T., 1969. Fundamental Research Statistics for the Behavioral Science. New York: Holt, Rinehart and Winston, Inc.

[47]. Rice, C.R. 2000. Factors Affecting the Competitiveness of small and Medium Enterprise in Indonesia. Work paper PEG, Unsaid (2000).

[48]. Solimun, 2002. Multivariate Analysis, Structural Equation Modeling (SEM), Lisrel dan Amos, aplikasi di manajemen, ekonomi pembangunan, psikologi, sosial, kedokteran dan agro kompleks. Malang: Fakultas MIPA, Universitas Brawijaya.

[49]. Spreitzer, G.M., 1995. Psychological empowerment in workplace: dimensions, measurement, and validation. Academy of Management Journal, 38(5), pp.1442-1465.

[50]. Suharyadi, 2007. Kewirausahaan; Membangun Usaha Sukses Sejak Usia Muda. Jakarta: Salemba Empat.

[51]. Sekaran, U. 2003. Research Methods for Business, a skill building approach. New York: John Wiley \& Sons, Inc.

[52]. Slater, S.F, and Narver, J.C. 1995. Market Orientation and the Learning organization. Journal of Marketing, 59: 63-74

[53]. Spreitzer, G.M. 1995. Psychological empowerment in workplace: dimensions, measurement, and validation. Academy of Management Journal, 38(5), pp.1442-1465

[54]. Tuckman, B.W., 1978. Conducting Educational Research. Sandiego: Harcourt Brace Jovanovich, Publishers.

[55]. Thomas, K. W., and Velthouse, B. A . (1990). "Cognitive Elements of Empow erment: A Interpretive" Model of Intrinsic Task Motivation. Academy of Management Review. Vol. 15, pp. 666-681.

[56]. Wong, Y.T., Ngo, H.Y., and Wong, C.S., 2002. Affective organizational commitment of workers in Chinese joint ventures. Journal of Managerial Psychology, 17 (7): 580-598.

[57]. Wood, Jack. Chapman, Judith. Wallace, Joseph. Zeffane, Rachid, MZeffane 2004 Organisational Behaviour: A Global Perspective. 3rd.

[58]. Yanghoubi, M., Raesi, A, Afshar M, Yarmohammadian, M.H. Hasanzadeh, A Javadi, M, Ansary M (2010), the relationship between the learning organization and organizational commitment among managers in educational hospitals of Isfahan University of medical Sciences in 2008 -9, IJNMR, Vol 15, No2, pp 78-84Edition, John Wiley \& Sons Australia, Ltd.

[59]. Xianting, Y., Fungfai, NG, Learning organization and Mentoring Practice : An Empirical Investigation, http/www. Eres 2010. Org/contents/paper /1d214.pdf diakses 10 februari 2014. 